\title{
Institutions and the resource curse ${ }^{1}$
}

\author{
Halvor Mehlum², Karl Moene ${ }^{3}$ and Ragnar Torvik ${ }^{4}$
}

16th March 2005

${ }^{1}$ We are grateful to two anonymous referees and editor Andrew Scott for their constructive suggestions. We also want to thank Jens Chr. Andvig, Carl-Johan Lars Dalgaard, James A. Robinson and a number of seminar participants for valuable comments.

${ }^{2}$ Department of Economics, University of Oslo P.O. Box 1095, Blindern N-0317 Oslo, Norway. E-mail: halvor.mehlum@econ.uio.no.

${ }^{3}$ Department of Economics, University of Oslo P.O. Box 1095, Blindern N-0317 Oslo, Norway. E-mail: k.o.moene@econ.uio.no.

${ }^{4}$ Corresponding author. Department of Economics, Norwegian University of Science and Technology, Dragvoll, N-7491 Trondheim, Norway. E-mail: ragnar.torvik@svt.ntnu.no 


\begin{abstract}
Countries rich in natural resources constitute both growth losers and growth winners. We claim that the main reason for these diverging experiences is differences in the quality of institutions. More natural resources push aggregate income down, when institutions are grabber friendly, while more resources raise income, when institutions are producer friendly. We test this theory building on Sachs and Warner's influential works on the resource curse. Our main hypothesis - that institutions are decisive for the resource curse - is confirmed. Our results contrast the claims of Sachs and Warner that institutions do not play a role.
\end{abstract}

Keywords: Natural resources, Institutional quality, Growth, Rent-seeking JEL: O4, Q0, F43 
One important finding in development economics is that natural resource abundant economies tend to grow slower than economies without substantial resources. For instance, growth losers, such as Nigeria, Zambia, Sierra Leone, Angola, Saudi Arabia, and Venezuela, are all resource-rich, while the Asian tigers: Korea, Taiwan, Hong Kong, and Singapore, are all resource-poor. On average resource abundant countries lag behind countries with less resources. ${ }^{1}$ Yet we should not jump to the conclusion that all resource rich countries are cursed. Also many growth winners such as Botswana, Canada, Australia, and Norway are rich in resources. Moreover, of the 82 countries included in a World Bank study five countries belong both to the top eight according to their natural capital wealth and to the top 15 according to per capita income (World Bank 1994).

To explain these diverging experiences this paper investigates to what extent growth winners and growth losers differ systematically in their institutional arrangements. As a first take we plot in Figure 1 the average yearly economic growth from 1965 to 1990 versus resource abundance in countries that have more than $10 \%$ of their GDP as resource exports. In our data set this group consists of 42 countries. Panel a) is based on data from all 42 countries and the plot gives a strong indication that there is a resource curse. In panel b) and c), however, we have split the sample in two subsamples of equal size, according to the quality of institutions (a measure to be discussed below). Now the indication of a resource curse only appears for countries with inferior institutions - panel b); while the indication of a resource curse vanishes for countries with better institutions - panel c). ${ }^{2}$ This basic result

\footnotetext{
${ }^{1}$ This is documented in Sachs and Warner (1995), (1997a,b), Auty (2001). See also Gelb (1988), Lane and Tornell (1996), and Gylfason, Herbertsson and Zoega (1999). Stijns (2002), however, argues that these results are less robust than the authors claim. It should furthermore be noted that concerns about specialising in natural resource exports was raised by economists well before the recent resource curse literature. Notably, Raol Prebisch and Hans Singer argued more than fifty years ago that countries relying on exports of primary goods would face sluggish growth of demand and declining terms of trade.

${ }^{2}$ The regression for the total sample of 42 countries (panel a) gives a correlation of $R^{2}=0.11$ and a significant slope of -6.15 . The regression for the 21 coutries with worst institutional quality (panel b) gives a $R^{2}$ of 0.35 and a significant slope of -8.46 . The regression for the 21 countries with the best institutional quality (panel c) gives a $R^{2}$ of 0.00 and a insignificant slope of -0.92 .

The countries in panel b) are numbered as follows: 1 Bolivia, 2 El Salvador, 3 Guyana, 4 Guatemala, 5 Philippines, 6 Uganda, 7 Zaire, 8 Nicaragua, 9 Nigeria, 10 Peru, 11 Honduras, 12 Indonesia, 13 Ghana, 14 Zambia, 15 Morocco, 16 Sri Lanka, 17 Togo, 18 Algeria, 19 Zimbabwe, 20 Malawi, 21 Dominican Rep.

The countries in panel c) are numbered as follows: 1 Tunisia, 2 Tanzania, 3 Madagascar, 4 Jamaica, 5 Senegal, 6 Gabon, 7 Ecuador, 8 Costa Rica, 9 Venezuela, 10 Kenya, 11 Gambia, 12
} 
Fig. 1: Resources and institutions

a) all resource rich countries

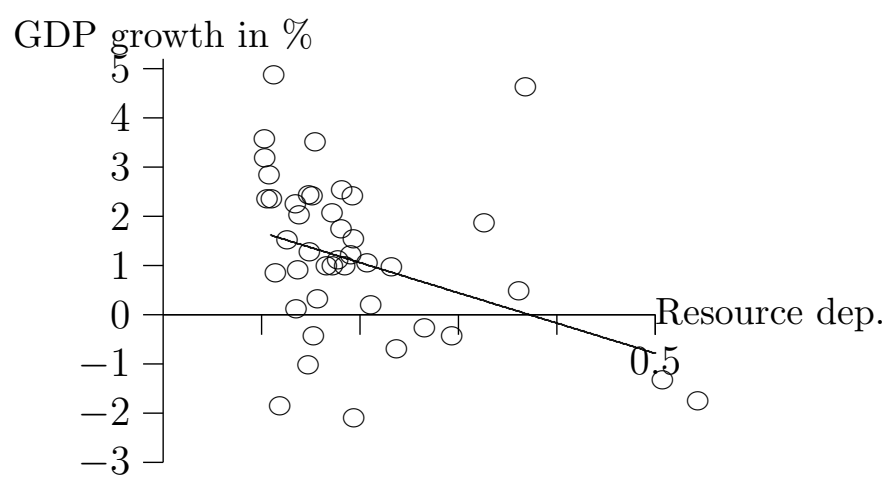

b) with bad institutions

c) with good institutions

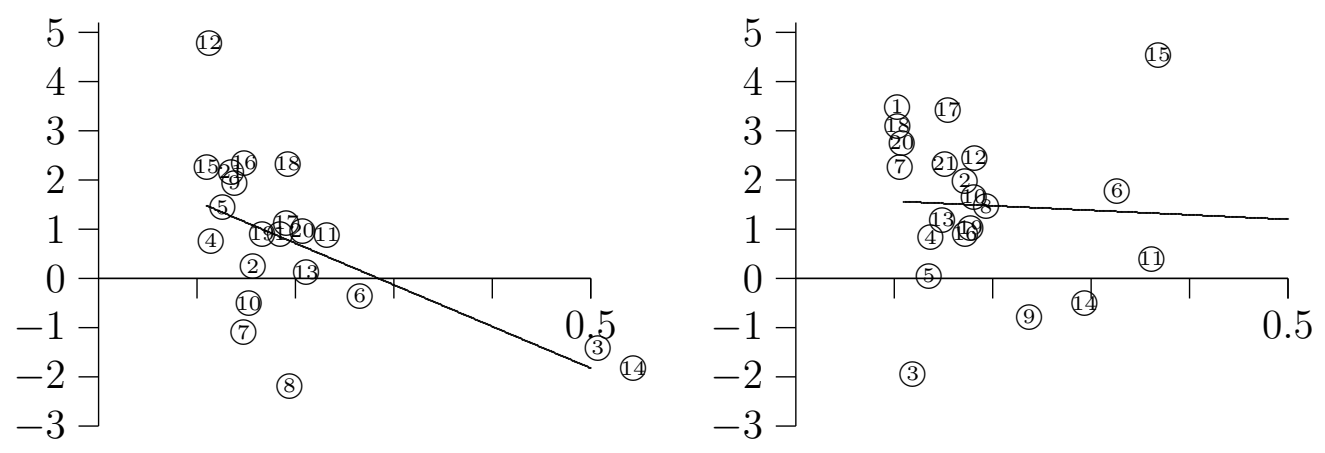


survives when we in the empirical section of the paper control for other factors.

On this basis we assert that the variance of growth performance among resource rich countries is primarily due to how resource rents are distributed via the institutional arrangement. ${ }^{3}$ The distinction we make is between producer friendly institutions, where rent-seeking and production are complimentary activities, and grabber friendly institutions, where rent-seeking and production are competing activities. With grabber friendly institutions there are gains from specialization in unproductive influence activities, for instance due to a weak rule of law, malfunctioning bureaucracy, and corruption. Grabber friendly institutions can be particularly bad for growth when resource abundance attracts scarce entrepreneurial resources out of production and into unproductive activities. With producer friendly institutions, however, rich resources attract entrepreneurs into production implying higher growth.

Our approach contrasts the rent seeking story that Sachs and Warner (1995) considered but dismissed in favour of a Dutch disease explanation. The rent seeking hypothesis they explored, states that resource abundance leads to a deterioration of institutional quality in turn lowering economic growth. Sachs and Warner found that this mechanism was empirically unimportant. However, the lack of evidence for institutional decay caused by resource abundance is not sufficient to dismiss the role of institutions. Institutions may be decisive for how natural resources affect economic growth even if resource abundance has no effect on institutions. We claim that natural resources put the institutional arrangements to a test, so that the resource curse only appears in countries with inferior institutions.

This hypothesis is consistent with observations from several countries. Botswana, with forty \% of GDP stemming from diamonds, has had the world's highest growth rate since 1965. Acemoglu, Johnson and Robinson (2002) attribute this remarkable performance to the good institutions of Botswana. (Among African countries Botswana has the best score on the Groningen Corruption Perception Index.) An-

Cameroon, 13 Chile, 14 Ivory Coast, 15 Malaysia, 16 South Africa, 17 Ireland, 18 Norway, 19 New Zealand, 20 Belgium, 21 Netherlands.

${ }^{3}$ In focusing on the decisive role of institutions for economic development we are inspired by North and Thomas (1973), Knack and Keefer (1995), Engerman and Sokoloff (2000), and Acemoglu, Johnson and Robinson (2001). 
other example is Norway - one of Europe's poorest countries in 1900, but now one of it's richest. The growth was led by natural resources such as timber, fish and hydroelectric power and more recently oil and natural gas. Norway is considered one of the least corrupt countries in the world. Similarly, in the century following 1850 USA exploited natural resources intensively. David and Wright (1997) argue that the positive feedbacks of this resource extraction explain much of the later economic growth. ${ }^{4}$

There are also many examples of slow growth among resource rich countries with weak institutions. Lane and Tornell (1996 and 1999) explain the disappointing economic performance after the oil windfalls in Nigeria, Venezuela, and Mexico by dysfunctional institutions that invite grabbing. Ades and Di Tella (1999) use crosscountry regressions to show how natural resource rents may stimulate corruption among bureaucrats and politicians. Acemoglu, Robinson and Verdier (2004) argue that higher resource rents make it easier for dictators to buy off political challengers. In Congo the "enormous natural resource wealth including 15 percent of the world's copper deposits, vast amounts of diamonds, zinc, gold, silver, oil, and many other resources [...] gave Mobutu a constant flow of income to help sustain his power." (p. 171) Resource abundance increases the political benefits of buying votes through inefficient redistribution. Such perverse political incentives of resource abundance are only mitigated in countries with adequate institutions. On this our approach complements recent political economy papers such as Acemoglu and Robinson (2002), Robinson, Torvik and Verdier (2002), and Acemoglu, Robinson and Verdier (2004).

Other examples of slow growth among resource rich countries are the many cases where the government is unable to provide basic security. In such countries resource abundance stimulate violence, theft, and looting, by financing rebel groups, warlord competition (Skaperdas 2002), or civil wars. In their study of civil wars Collier and Hoeffler (2000) find that "the extent of primary commodity exports is the largest single influence on the risk of conflict" (p. 26). The consequences for growth can be devastating. F.C. Lane argues that "the most weighty single factor in most periods of growth, if any one factor has been most important, has been a reduction in the

\footnotetext{
${ }^{4}$ See also Clay and Wright (2003) for a study of the California Gold Rush and the establishment of private institutions to regulate property rights and access to a nonrenewable resource.
} 
resources devoted to war" (1958 p. 413).

Our main focus in the theoretical part of the paper is the allocation of entrepreneurs between production and unproductive rent extraction (grabbing). Clearly grabbing harms economic development. Depending on the quality of institutions, however, lootable resources may or may not induce entrepreneurs to specialize in grabbing. In the empirical part we build on Sachs and Warner (1997a), whose result that natural resource abundance affects growth negatively has earlier been shown to be rather robust when controlling for other factors (see Sachs and Warner 1995, 1997a,b, 2001). We extend these growth regressions by allowing for the growth effects of natural resources to depend on the quality of institutions. Our main finding is that the resource curse applies in countries with grabber friendly institutions, but not in countries with producer friendly institutions.

This finding is consistent with our model, but is in contrast to earlier resource curse models, such as the Dutch disease models by van Wijnbergen (1984), Krugman (1987) and Sachs and Warner (1995), ${ }^{5}$ and the rent seeking models by Lane and Tornell (1996), Tornell and Lane (1999) and Torvik (2002). All these models imply that there is an unconditional negative relationship between resource abundance and growth.

\section{Grabbing versus production}

In the model the total number of entrepreneurs is denoted by $N=n_{P}+n_{G}$, where $n_{P}$ are producers while $n_{G}$ are grabbers. Grabbers target rents from natural resources $R$ and use all their capacity to appropriate as much as possible of this rent. To what extent grabbing succeeds depends on the institutions of the country. In the model the institutional quality is captured by the parameter $\lambda$, which reflects the degree to which the institutions favour grabbers versus producers. Formally $\lambda$ measures the resource rents accruing to each producer relative to that accruing to each grabber. When $\lambda=0$, the system is completely grabber friendly such that grabbers extract the entire rent, each of them obtaining $R / n_{G}$. A higher $\lambda$ implies a more producer friendly institutional arrangement. When $\lambda=1$, there are no gains from specialization in grabbing as both grabbers and producers each obtain

\footnotetext{
${ }^{5}$ See Torvik (2001) for a discussion of the Dutch disease models.
} 
the share $R / N$ of resources. In other words, $1 / \lambda$ indicates the relative resource gain from specializing in grabbing activities. In countries where $\lambda$ is low, this relative gain is large. Clearly, in this case rent appropriation and production are competing activities. In countries where $\lambda$ is higher, however, rent appropriation and production may become complementary. The higher is $\lambda$, the lower is the resource gain from specializing in grabbing and the less willing are entrepreneurs to give up the profits from production to become grabbers.

The pay-off $\pi_{G}$ to each grabber is a factor $s$ times $R / N$

$$
\pi_{G}=s R / N
$$

while each producer's share of the resource rent is $\lambda s R / N$. The factor $s$ is decreasing in $\lambda$ since each grabber gets less the more producer friendly the institutions. There is also a positive effect on $s$ from less competition between grabbers. Hence, the value of $s$ is an increasing function of the fraction of producers $\alpha=n_{P} / N$ and a decreasing function of the institutional parameter $\lambda$. The sum of shares of the resource rent that accrue to each group of entrepreneurs, cannot exceed one. Hence, the following constraint must hold

$$
(1-\alpha) s+\alpha \lambda s \leq 1
$$

To err on the safe side we assume that sharing of the resource rents does not imply direct waste. When no rents are wasted in the sharing, the condition (2) must hold with equality, implying that

$$
s=s(\alpha, \lambda) \equiv \frac{1}{(1-\alpha)+\lambda \alpha}
$$

In fact, $s(\alpha, \lambda)$ is a much used contest success function in the rent seeking literature, and is a special case of the function used by Tullock (1975).

The profits of a producer $\pi_{P}$ is the sum of profits from production $\pi$ and the share of the resource rents $\lambda s R / N$. Hence,

$$
\pi_{P}=\pi+\lambda s(\alpha, \lambda) R / N
$$


In order to determine profits from production, $\pi$, we now turn to the productive part of the economy. Since we are interested in how natural resources affect incentives to industrialize we embed our mechanism in a development model with joint economies in modernization. We follow Murphy, Shleifer, and Vishny's (1989) simple formalization of Rosenstein-Rodan's (1943) idea about demand complementarities between industries.

There are $L$ workers and $M$ different goods; each good can be produced in a modern firm or in a competitive fringe. In the fringe the firms have a constant returns to scale technology where one unit of labour produces one unit of the good. Hence, the real wage in the fringe and the equilibrium wage of the economy is equal to unity. A modern firm applies an increasing returns to scale technology. Each modern firm is run by one entrepreneur and requires a minimum of $F$ units of labour. Each worker beyond $F$ produces $\beta>1$ units of output. Hence, the marginal cost is $1 / \beta<1$.

Assuming equal expenditure shares in consumption, inelastic demand and Bertrand price competition, it follows that: (i) all $M$ goods are produced in equal quantities $y$ and all have a price equal to one. Hence total production is $M y$. (ii) each good is either produced entirely by the fringe or entirely by one single modern firm. To see this, observe that the fringe can always supply at a price equal to unity. Price competition à la Bertrand implies that the modern firm sets a price just below the marginal cost of its competitors. A single modern firm in an industry only competes against the fringe and the price is set equal to one. If a second modern firm enters the same industry competition drives the price down to $1 / \beta$, implying negative profits for both. Hence, only one modern firm will enter each branch of industry.

Profits from modern production are therefore

$$
\pi=\left(1-\frac{1}{\beta}\right) y-F
$$

Total income $Y$ consists of resource rents, $R$, in addition to the value added in production, $y M$. Total income $Y$ is also equal the sum of wage income, $L$, and the 
sum of profits to producers and grabbers:

$$
Y=R+M y=N\left(\alpha \pi_{P}+(1-\alpha) \pi_{G}\right)+L
$$

Inserting in (6) from (1) and (4) it follows when taking into account the no waste condition (3) that

$$
Y=R+M y=L+R+n_{P} \pi
$$

Combining the latter equality with (5), and solving for $y$, we get ${ }^{6}$

$$
y=\frac{\beta\left(L-n_{P} F\right)}{\beta\left(M-n_{P}\right)+n_{P}}
$$

In an economy without modern firms, total income is equal to $L+R$. In a completely industrialized economy $\left(n_{P}=\alpha N=M\right)$ total income equals $\beta(L-M F)+R$. We assume that the income in a completely industrialized economy is higher than in an economy without modern firms, implying that the marginal productivity in modern firms $\beta$ is sufficiently high:

$$
\beta(L-M F)+R>L+R \Longleftrightarrow \beta>\frac{L}{(L-M F)}
$$

We also assume that there always is a scarcity of producing entrepreneurs, implying that $N<M$. By inserting from (8) in (5) it follows that $\pi$ can be written as a function of the number of productive entrepreneurs

$$
\pi=\pi\left(n_{P}\right)
$$

We can show that as a result of $(9) \pi\left(n_{P}\right)$ is everywhere positive and increasing in

\footnotetext{
${ }^{6}$ Assuming that the natural resource $R$ consists of the same basket of goods that are previously produced in the economy, or (more realistic) that the natural resource is traded in a consumption basket equivalent to the one the country already consumes. This simplifies the analysis as production of all goods will be symmetric as in Murphy, Shleifer and Vishny (1989). For analysis of demand composition effects of natural resources, the cornerstone in the 'Dutch disease' literature, see for example van Wijnbergen (1984), Krugman (1987), Sachs and Warner (1995) and Torvik (2001). For rent-seeking models with demand composition effects, see Baland and Francois (2000) and Torvik (2002).
} 
Fig. 2: Resources and rent seeking

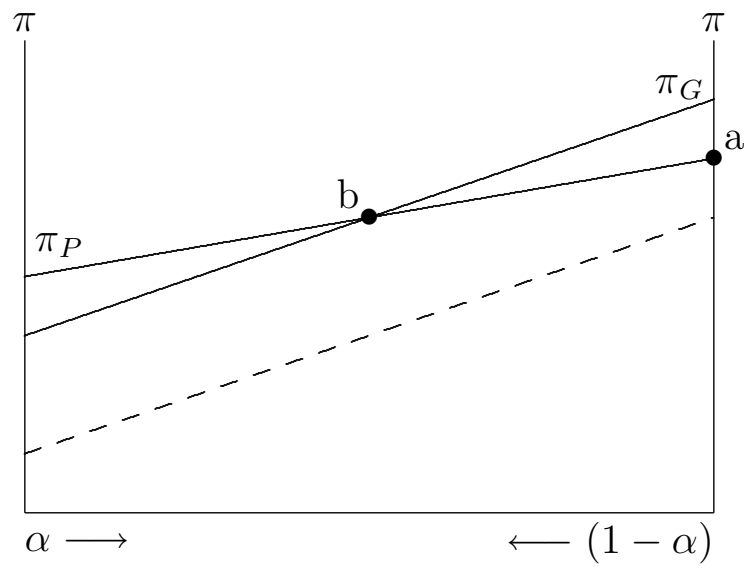

the number of producers $n_{P}=\alpha N .^{7}$ The total profits (including resource rents) to each producer are

$$
\pi_{P}=\pi(\alpha N)+\lambda s(\alpha, \lambda) R / N
$$

Or equivalently, using (1),

$$
\pi_{P}=\pi(\alpha N)+\lambda \pi_{G}
$$

The equilibrium allocation of entrepreneurs, between production and grabbing, is determined by the relative profits of the two activities from (1) and (11). Both profit functions $\pi_{G}$ and $\pi_{P}$ are increasing in the fraction of producers $\alpha$. This is illustrated in Figure 2, where the dashed curve represents a lower $\pi_{G}$-curve. The $\pi_{G}$-curve is high relative to the $\pi_{P}$-curve if the institutional quality $\lambda$ is low, the resource rent $R$ is high, or the number of entrepreneurs is low. In the following we assume that the number of entrepreneurs and the profitability of modern production are sufficiently high to rule out the possibility of equilibria without a single producer. Formally,

$$
\frac{R}{N} \leq \pi(0)
$$

This condition states that some entrepreneurs find it worthwhile to produce rather than to grab, even in cases where institutions are completely grabber friendly. It follows by inserting $\alpha=0$ and $\lambda=0$ in the inequality $\pi_{P} \geq \pi_{G}$.

Now the economy may be in one of the following two types of equilibria:

\footnotetext{
${ }^{7}$ Since $\pi$ is positive entrepreneurs will always choose to be active either as producers or grabbers.
} 
a) Production equilibrium, where all entrepreneurs are producers $\left(\pi_{P} \geq\right.$ $\pi_{G}$ and $\alpha=1$ ), is illustrated by point $\mathbf{a}$ in Figure 2. In this case $\pi_{G}$ is represented by the dashed curve in the figure.

b) Grabber equilibrium, where some entrepreneurs are producers and some are grabbers $\left(\pi_{P}=\pi_{G}\right.$ and $\left.\alpha \in(0,1)\right)$, is illustrated by point $\mathbf{b}$ in Figure 2 . In this case $\pi_{G}$ is drawn as a solid curve in the figure.

It follows from (7) that in the production equilibrium total income is

$$
Y=N \pi(N)+R+L
$$

In the grabber equilibrium the basic arbitrage equation $\pi_{P}=\pi_{G}$ can, when using (12), be expressed as

$$
\pi_{P}(1-\lambda)=\pi(\alpha N)
$$

The left-hand side of (15) is the excess resource rents that a grabber has to give up if he switches to become a producer. The right-hand side of (15) is the profit from modern production that is the gain achieved by switching. Total income in the grabber equilibrium can be found by combining (15) and (6)

$$
Y=\frac{N}{1-\lambda} \pi(\alpha N)+L
$$

Note that (13) implies that the $\pi_{P}$-curve starts out below the $\pi_{G^{-}}$curve. It follows from (12), since $\pi>0$, that when institutional quality is high relative to resource rents, the equilibrium is a production equilibrium; ${ }^{8}$ and when institutional quality is low relative to the resource rents, the equilibrium is a grabber equilibrium. There will be an institutional threshold $\lambda=\lambda^{*}$ that determines in which of the two equilibria an economy ends up . From the definitions of the equilibria the institutional threshold $\lambda^{*}$ is implicitly defined by $\pi_{G}=\pi_{P}$ and $\alpha=1$. Inserting from (3), (11), and (12) we get

$$
\lambda^{*} \equiv \frac{R}{R+N \pi(N)}
$$

and we have the following proposition

\footnotetext{
${ }^{8}$ Clearly, irrespective of $R$, entrepreneurs in a country with $\lambda \geq 1$ will never enter into grabbing.
} 
Proposition 1 When institutional quality is high, $\lambda \geq \lambda^{*}$, the equilibrium is a production equilibrium. When the institutional quality is low, $\lambda<\lambda^{*}$, the equilibrium is a grabber equilibrium.

This proposition shows how natural resources put the institutional arrangement to a test. The higher the resource rents $R$ relative to the potential production profits $N \pi(N)$, the higher is the institutional quality threshold $\lambda^{*}$. Accordingly, more resources require better institutions to avoid the grabber equilibrium.

The economic effects of higher resource rents in the two equilibria are quite different as the following proposition shows:

Proposition 2 More natural resources is a pure blessing in a production equilibrium - a higher $R$ raises national income. More natural resources is a curse in a grabber equilibrium - a higher $R$ lowers national income.

Proof. That national income goes up with $R$ in the production equilibrium follows directly from (14). The impact of a higher $R$ in the grabber equilibrium follows when inserting from (1) and (11) in the equilibrium condition $\pi_{P}=\pi_{G}$ and implicitly differenting $\alpha$ with respect to $R$

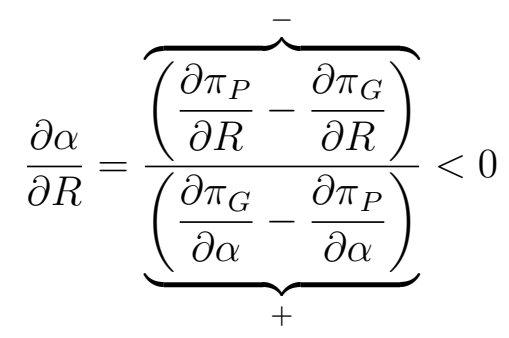

The sign of the numerator follows directly from the definitions of $\pi_{P}$ and $\pi_{G}$. The sign of the denominator follows as $\pi_{G}$ as a function of $\alpha$ crosses $\pi_{P}$ from below (cf Figure 1 and (13)). Knowing that $\alpha$ is decreasing in $R$ the proposition is immediate from (16).

The result that more resources reduce total income may appear paradoxical. There are two opposing effects: the immediate income effect of a higher resource rent $R$ is a one to one increase in national income; the displacement effect reduces national income as entrepreneurs move from production to grabbing. The resource curse follows as the displacement effect is stronger than the immediate income effect. An entrepreneur who moves out of production forgoes the profit from modern 
production $\pi\left(n_{P}\right)$, but obtains an additional share of the resource rent equal to $(1-\lambda) s R / N$. In equilibrium (15) these two values are equal. With more natural resources the additional resource rents to grabbers obviously go up. Hence, producers are induced to switch to grabbing until a new equilibrium is reached. It is a well-known result from the rent-seeking literature that a fixed opportunity cost of grabbing implies that a marginal rise in rents is entirely dissipated by more grabbing activities. Hence, in these models the displacement effect exactly balances the immediate income effect. In our case, however, the positive externality between producers implies that the opportunity cost of grabbing declines as entrepreneurs switch from production to grabbing. The declining opportunity cost magnifies the displacement effect and explains why the displacement effect eventually is stronger than the immediate income effect. ${ }^{9}$

The extent of rent dissipation also depends on the quality of institutions:

Proposition 3 In the grabber equilibrium (i.e. $\lambda<\lambda^{*}$ ) more producer friendly institutions (higher values of $\lambda$ ) increase profits both in grabbing and production, and thus leads to higher total income. In the production equilibrium (i.e. $\lambda \geq \lambda^{*}$ ) a further increase in $\lambda$ has no implications for total income.

Proof. The first part is evident from (15). The last part is evident from (14).

Interestingly, worse opportunities for grabbers raise their incomes. The reason is that a higher value of $\lambda$ induces entrepreneurs to shift from grabbing to production. As a consequence, the national income goes up, raising the demand for modern commodities, and thereby raising producer profits even further. In the new equilibrium profits from grabbing and from production are equalized at a higher level.

The extent of grabbing is also determined by the total number of entrepreneurs as stated in the following proposition:

Proposition 4 In the grabber equilibrium a higher number of entrepreneurs $N$

\footnotetext{
${ }^{9}$ In our model resource rents in each period are exogenous. Of course, if more grabbers also mean that resources are increasingly overexploited, the effect of more grabbers may be even worse than predicted by the model. For a political economy model of overexploitation of natural resources, see Robinson, Torvik and Verdier (2002).
} 
raises the number of producers $n_{P}$, lowers the number of rent-seekers $n_{G}$, and leads to higher profits in both activities.

Proof. By differentiating the equilibrium condition $\pi_{P}=\pi_{G}$, and reasoning as in the proof of Proposition 2, it follows that $\partial \alpha / \partial N>0$. Hence, as $n_{P}=\alpha N$, the value of $n_{P}$ unambiguously increases with $N$. From (15) it follows that the common level of profits in grabbing and production must go up. Finally, it follows, when plugging (3) into (1), that $\pi_{G}=R /\left(n_{G}+\lambda n_{P}\right)$. Now, since both $n_{P}$ and $\pi_{G}$ increase, the number of grabbers $n_{G}$ must decline.

The proposition states that a higher number of entrepreneurs is a double blessing. Not only do all new entrepreneurs go into production, but their entrance also induces existing grabbers to shift over to production. The reason is the positive externality in modern production. The proposition also states that grabbing is most severe - both absolutely and relatively - in economies where the total number of entrepreneurs is low. These results are important for the dynamics to which we now turn.

The growth of new entrepreneurs is assumed to be a fixed inflow $\theta$ of new entrepreneurs minus the exit rate $\delta$ times the number of entrepreneurs $N$, expressed as $d N / d t=\theta-\delta N$. When this is the case the number of entrepreneurs will grow until it reaches the long-run steady state level equal to $\bar{N}=\theta / \delta$. Countries that have little natural resources or good institutions, will in the long run end up in a production equilibrium. Using the definition of the institutional threshold $\lambda^{*}$ in (17) we define a resource threshold $R^{*}$ such that

$$
\lambda=\lambda^{*} \equiv \frac{R}{R+\bar{N} \pi(\bar{N})} \Longleftrightarrow R=\frac{\lambda}{1-\lambda} \bar{N} \pi(\bar{N}) \equiv R^{*}(\bar{N}, \lambda)
$$

A country with institutional quality $\lambda$ and with long run number of entrepreneurs $\bar{N}$ will end up in a production equilibrium if and only if $R<R^{*}(\bar{N}, \lambda)$. This condition assures that the resource rents (relative to the quality of institutions) is not high enough to make grabbing attractive when the total number of entrepreneurs has reached its steady state level $\bar{N}$. Countries with more resources, $R>R^{*}(\bar{N}, \lambda)$, are in the long run not able to avoid the grabber equilibrium.

To see how the dynamics work consider Figure 3 where we measure the number of productive entrepreneurs $n_{P}$ on the horizontal axis and the value of resources $R$ 
Fig. 3: Resources and rent seeking

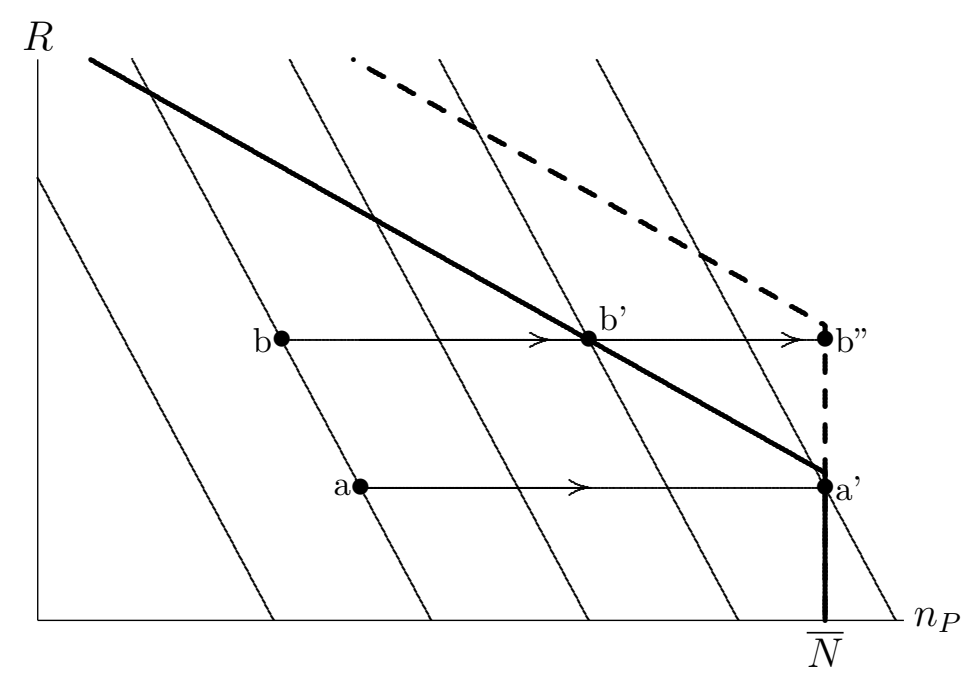

on the vertical axis. From (1), (3), and (15) it follows that in a grabber equilibrium the long run relationship between $R$ and $n_{P}$ is

$$
R=\frac{\bar{N}}{1-\lambda} \pi\left(n_{P}\right)-n_{P} \pi\left(n_{P}\right)
$$

In the producer equilibrium, however, $n_{P}$ is by definition equal to $\bar{N}$. Thus the long run relationship in Figure 3 has a kink for $n_{P}=\bar{N}$. The kink defines the separation between the grabber and the producer equilibrium and is thus given by $R^{*}$.The long run relationship between $R$ and $n_{P}$ is given by the bold curve in Figure 3 .

In the figure we have also drawn iso-income curves. Each curve is downward sloping as more natural resources are needed to keep the total income constant when the number of producers declines. For a fixed total income $Y=Y_{i}$, an iso-income curve is from (7) given by

$$
R=-L-n_{P} \pi\left(n_{P}\right)+Y_{i}
$$

By comparing this expression with (19) we see that the iso-income curves are steeper than the long run equilibrium curve, as depicted in Figure 3.

We are now ready to illustrate the implications of resource abundance and institutions on income growth. We first focus on two countries, $\mathrm{A}$ and $\mathrm{B}$, that have the same quality of institutions (the same $\lambda$ ) and by construction the same initial income level. Country A has little resources, but a high number of producers, while 
country B has more resources and fewer producers. Country A, that starts out in point a, ends up in point a', while country B, that starts out in point b, ends up in point b'.

As seen from the figure the resource rich country B ends up at a lower income level than the resource poor country A. The reason is that country A because of its lack of resources, ends up in the production equilibrium, while country B because of its resource abundance ends up in the grabber equilibrium. Accordingly, over the transition period growth is lowest in the resource rich country. This is a specific example of a more general result. As proved in Proposition 2, country B would increase its growth potential if it had less resources.

Assume next that country B instead had more producer friendly institutions and thus a higher $\lambda$ than country A. As country B now is more immune to grabbing, it can tolerate its resource abundance and still end up in the production equilibrium. As a result, the long run equilibrium curve for country B shifts up, as illustrated by the dotted curve in Figure 2. With grabber friendly institutions (low $\lambda$ ) country B converges to point b', while with producer friendly institutions (high $\lambda$ ) country B converges to point b". Income is higher in b" than in b'. Over the transition period growth is therefore highest with producer friendly institutions. Moreover with more producer friendly institutions the resource rich country B outperforms the resource poor country A, eliminating the resource curse.

\section{Empirical Testing}

Our main prediction is that the resource curse - that natural resource abundance is harmful for economic development - only hits countries with grabber friendly institutions. Thus countries with producer friendly institutions will not experience any resource curse. Natural resource abundance does therefore hinder economic growth in countries with grabber friendly institutions, but does not in countries with producer friendly institutions.

This prediction challenges the Dutch disease explanation of the resource curse, emphasized in the empirical work by Sachs and Warner (1995 and 1997a). They dismiss one rent-seeking mechanism by showing that there is at most a weak impact of resource abundance on institutional quality. Hence, resource abundance does not 
cause a deterioration of institutions. They do not, however, consider our hypothesis that a poor quality of institutions is the cause of the resource curse and that good enough institutions can eliminate the resource curse entirely. If our hypothesis is supported by the data, the role of institutions is confirmed and the Dutch disease story is less palatable.

In order to test our hypothesis against Sachs and Warner's we use their data and methodology. All the data are from Sachs and Warner and are reproduced in the appendix. For a complete description of the data sources we refer to Sachs and Warner (1997b). Our sample consists of 87 countries, limited only by data availability. We use Sachs and Warner's Journal of African Economies article (1997b) rather than the Harvard mimeo (1997a). The reason is that the data series in the Journal of African Economies article covers a longer period, a larger number of countries, and contains a more suitable measure of institutional quality. ${ }^{10}$

The dependent variable is: GDP growth - average growth rate of real GDP per capita between 1965 and 1990. Explanatory variables are: initial income level the log of GDP per head of the economically active population in 1965; openness - an index of a country's openness in the same period; resource abundance - the share of primary exports in GNP in 1970; investments - the average ratio of real gross domestic investments over GDP, and finally institutional quality - an index ranging from zero to unity.

The institutional quality index is an unweighted average of five indexes based on data from Political Risk Services: a rule of law index, a bureaucratic quality index, a corruption in government index, a risk of expropriation index, and a government repudiation of contracts index. ${ }^{11}$ All these characteristics capture various aspects of producer friendly versus grabber friendly institutions. The index runs from one (maximum producer friendly institutions) to zero. Hence, when the index is zero, there is a weak rule of law and a high risk of expropriation, malfunctioning bureaucracy and corruption in the government; all of which favour grabbers and deter

\footnotetext{
${ }^{10}$ The data used in both papers can be downloaded from Centre for International Development at http://www.cid.harvard.edu/ciddata/ciddata.html

In the appendix we have reported our main regression using the data from (1997a). The results differ only marginally from the results reported below.

${ }^{11}$ A more detailed description of the index is provided by Knack and Keefer (1995).
} 
producers.

Table 1: Regression results I.

\begin{tabular}{lrrrr}
\hline Dependent variable: GDP growth. & & & \\
\hline \hline & Regression 1 & Regression 2 & Regression 3 & Regression 4 \\
\hline \multirow{2}{*}{ initial income level } & $-0.79^{*}$ & $-1.02^{*}$ & $-1.28^{*}$ & $-1.26^{*}$ \\
& $(-3.80)$ & $(-4.38)$ & $(-6.65)$ & $(-6.70)$ \\
openness & $3.06^{*}$ & $2.49^{*}$ & $1.45^{*}$ & $1.66^{*}$ \\
& $(7.23)$ & $(4.99)$ & $(3.36)$ & $(3.87)$ \\
resource abundance & $-6.16^{*}$ & $-5.74^{*}$ & $-6.69^{*}$ & $-14.34^{*}$ \\
& $(-4.02)$ & $(-3.78)$ & $(-5.43)$ & $(-4.21)$ \\
institutional quality & & $2.2^{*}$ & 0.6 & -1.3 \\
& & $(2.04)$ & $(0.64)$ & $(-1.13)$ \\
investments & & & $0.15^{*}$ & $0.16^{*}$ \\
interaction term & & & $(6.73)$ & $(7.15)$ \\
Observations & & & & $15.4^{*}$ \\
Adjusted $\mathrm{R}^{2}$ & 87 & 87 & 87 & $(2.40)$ \\
Note: The & 0.50 & 0.52 & 0.69 & 0.71 \\
\hline
\end{tabular}

Note: The numbers in brackets are t-values. A star $\left(^{*}\right)$ indicates that the estimate is significant at the 5-\% level.

Our first regression confirms Sachs and Warner's (1995 and 1997a) results on convergence, openness, and natural resource abundance. ${ }^{12}$

In regressions 2 and 3 we successively include institutional quality and investment share of GDP, which both have a positive impact on growth. When investment is included, however, institutional quality does no longer have a significant effect.

So far our estimates have added nothing beyond what Sachs and Warner showed. Regression 4, however, provides the new insights to the understanding of the resource curse. In this regression we include the interaction term that captures the essence of our model prediction:

$$
\text { interaction term }=[\text { resource abundance }] *[\text { institutional quality }]
$$

Our prediction is that the resource abundance is harmful to growth only when the institutions are grabber friendly. Therefore we should expect that the interaction

\footnotetext{
${ }^{12}$ The minor differences in the estimated coefficients between our regression and Sachs and Warner's are caused by different starting years (ours is 1965, while theirs is 1970) and that they exclude outliers. In the appendix we include regression results that exactly reproduce Sachs and Warner (1997a) using their data.
} 
term has a positive coefficient. This is indeed what we find. The effect from the interaction term is both strong and significant (with a p-value of 0.019).

The growth impact of a marginal increase in resources implied by regression 4 is

$$
\frac{d[\text { growth }]}{d[\text { resource abundance }]}=-14.34+15.40[\text { institutional quality }]
$$

We see that the resource curse is weaker the higher the institutional quality. Moreover, for countries with high institutional quality (higher than the threshold $14.34 / 15.40=0.93)$ the resource curse does not apply. As shown in the appendix, 15 of the 87 countries in our sample have the sufficient institutional quality to neutralize the resource curse.

As mentioned in the introduction there are five countries that belong both to the top eight according to their natural capital wealth and to the top 15 according to per capita income. Of these countries United States, Canada, Norway, and Australia have an institutional quality above the threshold. The fifth, Ireland, follows close with an index value of 0.83 .

Our results are also confirmed in the regressions contained in the appendix where we use exactly the same data and countries as Sachs and Warner (1997a). As they did, we there use the rule of law as an indicator of the institutional quality.

One concern is that resource abundance might be correlated with some measure of underdevelopment not included in our analysis. For instance, underdevelopment can be associated with specialization in agricultural exports, and this may drive the empirical results. Our mechanism of resource grabbing is less likely to apply in agrarian societies, as land is less lootable and taxable than most natural resources. Therefore we investigate how the results are affected by using an alternative resource measure that concentrate on lootable resources. In Regression 1 in Table 2 we use mineral abundance - the share of mineral production in GNP in 1971 from Sachs and Warner (1995).

The regression shows that the direct negative effect of natural resources becomes stronger and that the interaction effect increases substantially. Since resources that are easily lootable appear to be particularly harmful for growth in countries with weak institutions, our grabbing story receives additional support. A more detailed 
Table 2: Regression results II.

\begin{tabular}{|c|c|c|c|c|c|c|}
\hline \multicolumn{7}{|c|}{ Dependent variable: GDP growth. } \\
\hline & Regression 1 & Regression 2 & Regression 3 & $\begin{array}{l}\text { Regression } 4 \\
\end{array}$ & 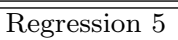 & $\begin{array}{l}\text { Regression } 6 \\
\end{array}$ \\
\hline initial income level & $\begin{array}{l}-1.33^{*} \\
(-6.26)\end{array}$ & $\begin{array}{l}-1.88^{*} \\
(-7.95)\end{array}$ & $\begin{array}{l}-1.33^{*} \\
(-5.90)\end{array}$ & $\begin{array}{c}-1.34^{*} \\
(-6.97)\end{array}$ & $\begin{array}{l}-1.36^{*} \\
(-6.13)\end{array}$ & $\begin{array}{l}-1.45^{*} \\
(-5.45)\end{array}$ \\
\hline openness & $\begin{array}{l}1.87^{*} \\
(3.77)\end{array}$ & $\begin{array}{l}1.34^{*} \\
(3.20)\end{array}$ & $\begin{array}{l}1.60^{*} \\
(3.47)\end{array}$ & $\begin{array}{l}1.59^{*} \\
(3.73)\end{array}$ & $\begin{array}{l}1.63^{*} \\
(3.76)\end{array}$ & $\begin{array}{l}1.56^{*} \\
(3.36)\end{array}$ \\
\hline resource abundance & & $\begin{array}{l}-10.92^{*} \\
(-3.16)\end{array}$ & $\begin{array}{l}-16.35^{*} \\
(-3.71)\end{array}$ & $\begin{array}{l}-13.70^{*} \\
(-4.00)\end{array}$ & $\begin{array}{c}14.78^{*} \\
(-4.26)\end{array}$ & $\begin{array}{l}-16.25^{*} \\
(-3.60)\end{array}$ \\
\hline mineral abundance & $\begin{array}{l}-17.71^{*} \\
(-3.16)\end{array}$ & & & & & \\
\hline institutional quality & $\begin{array}{r}-0.20 \\
(-0.22)\end{array}$ & $\begin{array}{r}1.83 \\
(-1.35)\end{array}$ & $\begin{array}{r}-0.90 \\
(-0.69)\end{array}$ & $\begin{array}{r}-1.15 \\
(-0.96)\end{array}$ & $\begin{array}{c}-1.18 \\
(-0.94)\end{array}$ & $\begin{array}{l}-0.78 \\
(-0.56)\end{array}$ \\
\hline investments & $\begin{array}{l}0.15^{*} \\
(6.25)\end{array}$ & $\begin{array}{l}0.11^{*} \\
(4.09)\end{array}$ & $\begin{array}{l}0.15^{*} \\
(5.56)\end{array}$ & $\begin{array}{l}0.15^{*} \\
(6.51)\end{array}$ & $\begin{array}{l}0.15^{*} \\
(6.76)\end{array}$ & $\begin{array}{l}0.14^{*} \\
(4.91)\end{array}$ \\
\hline interaction term & $\begin{array}{l}29.43^{*} \\
(2.66)\end{array}$ & $\begin{array}{l}11.01 \\
(1.84)\end{array}$ & $\begin{array}{l}18.31^{*} \\
(2.34)\end{array}$ & $\begin{array}{l}15.86^{*} \\
(2.45)\end{array}$ & $\begin{array}{l}16.84^{*} \\
(2.55)\end{array}$ & $\begin{array}{l}19.01^{*} \\
(2.41)\end{array}$ \\
\hline secondary & & & $\begin{array}{c}-0.60 \\
(-0.44)\end{array}$ & & & $\begin{array}{l}-0.57 \\
(-0.41)\end{array}$ \\
\hline ethnic frac. & & & & $\begin{array}{l}-0.88 \\
(1.69)\end{array}$ & & $\begin{array}{l}-0.77 \\
(1.12)\end{array}$ \\
\hline language frac. & & & & & $\begin{array}{l}-0.36 \\
(0.75)\end{array}$ & $\begin{array}{c}-0.11^{*} \\
(0.18)\end{array}$ \\
\hline Africa exluded & no & yes & no & no & no & no \\
\hline Observations & 87 & 59 & 76 & 86 & 84 & 74 \\
\hline Adjusted $R^{2}$ & 0.63 & 0.79 & 0.70 & 0.71 & 0.70 & 0.70 \\
\hline
\end{tabular}

Note: The numbers in brackets are t-values. A star $\left(^{*}\right)$ indicates that the estimate is significant at the 5-\% level.

exploration of how different types of resources, in combination with institutions, affect economic growth has been done by Boschini, Pettersson and Roine (2004). They use four different measures of resource abundance, and show that institutions are more decisive the more appropriable the natural resources.

A possible worry is that the resource curse mechanism might be purely an African phenomenon and that it does not apply to other countries. In regression 2 in Table 2 we exclude African countries from the analysis. As seen the coefficients keep their signs, while their values are somewhat reduced. We conclude from this that the effects that we have identified in Table 1, are not solely related to African experiences and that they are not artefacts stemming from systematic differences between African and Non-African countries.

Another worry is that our estimates may be biased by leaving out important explanatory variables. In regression 3 in Table 2 we investigate whether our results survive when we control for the level of education by the secondary school enrolment rate - secondary - from Sachs and Warner (1995). Compared to the estimates in regression 4 in Table 1 , the coefficients on resource abundance increase marginally. Moreover, there seems to be no clear connection between the secondary school enrolment rate and growth in our sample. In regressions 4 and 5 in Table 2 we control 
for ethnic fractionalization - ethnic -, and language fractionalization - lang - from Alesina et al. (2003). Controlling for these variables again only changes the results marginally. This indicates that the growth disruptive effects that we identify are due to resources and institutions rather than ethnic conflicts. In regression 6 we include all three variables above. As seen, our estimated coefficients are quite stable and remain significant.

In our regressions there may be problems of reverse causality. Sachs and Warner (1997a and 2001) address the aspect of reverse causality between the measure of growth and the measure of natural resource abundance. They find no evidence of this. Another possibility is that the quality of institutions itself is determined by GDP. This aspect of reverse causality is addressed in Acemoglu, Johnson and Robinson (2001). They show, by using settler mortality as an instrument for institutional quality, that the effect of institutions on income becomes stronger. Furthermore, Boschini, Pettersson and Roine (2004) show (for a somewhat different time period than ours) that the interaction effect between resources and institutional quality is strong and significant also when institutional quality is instrumented with the fraction of the population speaking an European language and by latitude. When Boschini, Pettersson and Roine (2004) instrument for institutions, using settler mortality, the sample becomes smaller. The signs of the estimated coefficients remain, but some become insignificant. ${ }^{13}$

Finally, we test our main prediction by applying Barro-type growth regressions. We could have worked with level regressions with income at the end of the period as the dependent variable - an approach similar to those of Hall and Jones (1999) and Acemoglu, Johnson and Robinson (2001). To apply level regressions in our case requires another measure of resource abundance. We measure resource abundance relative to GDP. All else being equal, countries with high GDP would appear as resource scarce, while countries with a low GDP would appear as resource abundant. In regressions controlling for initial income this problem does not arise.

\footnotetext{
${ }^{13}$ Institutions may also be endogenous with respect to natural resources, as argued for instance by Ross $(2001 \mathrm{a}, \mathrm{b})$. Resource abundance may give politicians incentives to destroy institutions in order to be able to grab the resource rents, or to suppress democracy for the same reason. Note that this multicollinearity is not a major concern for the empirical results as the correlation between institutions and resource abundance is weak, see Sachs and Warner (1995).
} 
Clearly, using level regressions and controlling for initial income is in effect a growth regression.

\section{Concluding remarks}

Countries rich in natural resources constitute both growth losers and growth winners. We have shown that the quality of institutions determines whether countries avoid the resource curse or not. The combination of grabber friendly institutions and resource abundance leads to low growth. Producer friendly institutions, however, help countries to take full advantage of their natural resources. These results contrast the claims of Sachs and Warner that institutions are not decisive for the resource curse.

Our results also contrast the most popular Dutch disease explanations of the resource curse, that emphasize how natural resources crowd out growth generating traded goods production. Why should the crowding out of the traded goods sector be directly related to institutional quality? In particular it is hard to argue that the Dutch disease is closely related to the rule of law. In the appendix we use the rule of law as our measure of institutional quality confirming our results. We take this as further evidence that the dangerous mix of weak institutions and resource abundance causes the resource curse. 


\section{References}

Acemoglu, D., Johnson, S. and Robinson, J.A. (2001). 'The colonial origins of comparative development: an empirical investigation', American Economic Review, vol. 91, pp. 1369-401.

Acemoglu, D., Johnson, S. and Robinson, J.A. (2002). 'An African success: Botswana', in (D. Rodrik ed.) Analytic Development Narratives, Princeton: Princeton University Press.

Acemoglu, D. and Robinson, J.A. (2002). 'Economic backwardness in political perspective', NBER Working Paper No. 5398.

Acemoglu, D., Robinson, J.A. and Verdier, T. (2004). 'Kleptocracy and divide-andrule: a theory of personal rule', Journal of the European Economic Association, vol. 2, pp. 162-92.

Ades, A. and Di Tella, R. (1999). 'Rents, competition, and corruption', American Economic Review, vol. 89, pp. 982-93.

Alesina, A., Devleeschauwer, A., Easterly, W., Kurlat, S. and Wacziarg, R. (2003). 'Fractionalization', Journal of Economic Growth, vol. 8, pp. 155-94.

Auty R.M. (2001). Resource Abundance and Economic Development, Oxford: Oxford University Press.

Boschini, A.D., Pettersson, J. and Roine, J. (2004). 'Resource curse or not: a question of appropriability', Working Paper, Department of Economics, Stockholm University.

Baland, J.-M. and Francois, P. (2000). 'Rent-seeking and resource booms', Journal of Development Economics, vol. 61, pp. 527-42.

Clay, K. and Wright, G. (2003). 'Order without law? Property rights during the California gold rush', John M. Ohlin Program in Law and Economics Working Paper 265, Stanford Law School.

Collier, P and Hoeffler, A. (2000). 'Greed and grievance in civil war', World Bank Policy Research Paper 2355. 
David, P.A. and Wright, G. (1997). 'Increasing returns and the genesis of American resource abundance', Industrial and Corporate Change, vol. 6, pp. 203-45.

Engerman, S. L. and Sokoloff, K.L. (2000). 'Institutions, factor endowments, and paths of development in the New World', Journal of Economic Perspectives, vol. 14(3), pp. 217-32.

Gelb A. (1988). Windfall Gains: Blessing or Curse?, Oxford: Oxford University Press.

Gylfason, T., Herbertsson, T.T. and Zoega, G. (1999). 'A mixed blessing: natural resources and economic growth', Macroeconomic Dynamics, vol. 3, pp. 204-25.

Hall, R.E. and Jones, C.I. (1999). 'Why do some countries produce so much more output per-worker than others?', Quarterly Journal of Economics, vol. 114, pp. 83-116.

Knack, S. and Keefer, P. (1995). 'Institutions and economic performance: crosscountry tests using alternative institutional measures', Economics and Politics, vol. 7 , pp. 207-27.

Krugman, P. (1987). 'The narrow moving band, the Dutch disease, and the competitive consequences of Mrs. Thatcher: notes on trade in the presence of dynamic scale economies', Journal of Development Economics, vol. 37, pp. 41-55.

Lane, F.C. (1958). 'Economic consequences of organized violence', Journal of Economic History, vol. 58, pp. 401-17.

Lane, P.R. and Tornell, A. (1996). 'Power, growth and the voracity effect', Journal of Economic Growth, vol. 1, pp. 213-41.

Murphy, K., Shleifer, A. and Vishny, R. (1989). 'Industrialization and the big push', Journal of Political Economy, vol. 97, pp. 1003-26.

Robinson, J.A., Torvik, R. and Verdier, T. (2002). 'Political foundations of the resource curse', CEPR Discussion Paper No. 3422.

Rosenstein-Rodan, P. (1943). 'Problems of industrialisation of Eastern and SouthEastern Europe', The Economic Journal, vol, 53(210/211), pp. 202-11. 
Ross, M.L. (2001a). Timber Booms and Institutional Breakdown in Southeast Asia, New York: Cambridge University Press.

Ross, M.L. (2001b). 'Does oil hinder democracy?', World Politics, vol. 53, pp. 32561.

Sachs, J.D. and Warner, A.M. (1995). 'Natural resource abundance and economic growth', NBER Working Paper No. 5398.

Sachs, J.D. and Warner, A.M. (1997a). 'Natural resource abundance and economic growth - revised version', Working Paper, Harvard University.

Sachs, J.D. and Warner, A.M. (1997b). 'Sources of slow growth in African economies', Journal of African Economies, vol. 6, pp. 335-76.

Sachs, J.D. and Warner, A.M. (2001). 'The curse of natural resources', European Economic Review, vol. 45, pp. 827-38.

Skaperdas, S. (2002). 'Warlord competition', Journal of Peace Research, vol. 39, pp. 435-46.

Stijns, J.P. (2002). 'Natural resource abundance and economic growth revisited', Working Paper, Department of Economics, UC Berkeley.

Tornell, A. and Lane, P.R. (1999). 'The voracity effect', American Economic Review, vol. 89, pp. 22-46.

Torvik, R. (2001). 'Learning by doing and the Dutch disease', European Economic Review, vol. 45, pp. 285-306.

Torvik, R. (2002). 'Natural resources, rent seeking and welfare', Journal of Development Economics, vol. 67, pp. 455-70.

Tullock, G. (1975). 'On the efficient organization of trials', Kyklos, vol. 28, pp. 74562.

van Wijnbergen, S. (1984). 'The 'Dutch disease': a disease after all?', The Economic Journal, vol. 94, pp. 41-55. 
World Bank (1994). 'Expanding the measure of wealth: indicators of environmentally sustainable development', Environmentally sustainable development studies and monographs series no. 7 . 


\section{A Appendix}

\section{Regression results with Sachs and Warners (1997a) data.}

In this appendix we report the regression result when we use the data that Sachs and Warner (1997a) used. The first column exactly replicates their result. The second column reports our regression 4 with their data. Observe that rule of law has taken the place as our indicator of institutional quality, both as a stand alone variable and in the interaction term. When interpreting the results keep in mind that the rule of law index runs from 0-6 while the institutional quality index runs from 0 to 1 .

\begin{tabular}{lrr}
\hline \hline & Sachs and Warner's regression & Regression 4 (alternative) \\
\hline initial income level & $-1.76^{*}$ & $-1.82^{*}$ \\
& $(-8.56)$ & $(-8.96)$ \\
openess & $1.33^{*}$ & $1.53^{*}$ \\
& $(3.35)$ & $(3.82)$ \\
resource abundance & $-10.57^{*}$ & $-16.36^{*}$ \\
& $(-7.01)$ & $(-5.06)$ \\
rule of law & $0.36^{*}$ & 0.18 \\
& $(3.54)$ & $(1.32)$ \\
investments & $1.02^{*}$ & $0.95^{*}$ \\
& $(3.45)$ & $(3.28)$ \\
interaction term & & $1.96^{*}$ \\
Observations & 71 & $(2.01)$ \\
Adjusted $\mathrm{R}^{2}$ & 0.72 & 71 \\
Note: The numbers in brackets are t-values. & A star $\left(^{*}\right)$ indicates that the estimate is \\
significant at the 5-\% level. & &
\end{tabular}

Table 3: Regression results. Dependent variable is GDP growth.

The data are downloaded from Centre for International Development at http://www.cid.harvard.edu/ciddata/ciddata.html. A short description of the data are as follows (For a complete description consult Sachs and Warner 1997a): initial income level — natural log of real GDP divided by the economically-active population in 1970. GDP growth - average annual growth in real GDP divided by the economically active population between 1970 and 1990. resource abundance - share of exports of primary products in GNP in 1970. openness - the fraction of years during the period 1970-1990 in which the country is rated as an open economy. investments - log of the ratio of real gross domestic investment (public 
plus private) to real GDP averaged over the period 1970-1989. rule of law - an index constructed by the Center for Institutional Reform and the Informal Sector which reflects the degree to which the citizens of a country are willing to accept the established institutions to make and implement laws and adjudicate disputes. Scores 0 (low) - 6 (high). Measured as of 1982. interaction — variable constructed by multiplying rule of law with resource abundance. 


\begin{tabular}{|c|c|c|c|c|c|c|}
\hline COUNTRY & IQ & LGDPEA & SXP & OPEN & INV & GDP6590 \\
\hline BOLIVIA & 0.23 & 7.82 & 0.18 & 0.77 & 15.34 & 0.85 \\
\hline HAITI & 0.26 & 7.40 & 0.08 & 0.00 & 6.64 & -0.25 \\
\hline EL SALVADOR & 0.26 & 8.15 & $\begin{array}{l}0.00 \\
0.16\end{array}$ & 0.04 & $\begin{array}{l}.04 \\
8.19\end{array}$ & $\begin{aligned}-0.20 \\
0.19\end{aligned}$ \\
\hline BANGLADESH & 0.27 & 7.68 & 0.01 & 0.00 & 3.13 & $\begin{array}{l}0.19 \\
0.76\end{array}$ \\
\hline GUATEMALA & 0.28 & 8.16 & 0.11 & 0.12 & 9.19 & 0.71 \\
\hline GUYANA & 0.28 & 8.06 & 0.51 & 0.12 & 20.23 & -1.47 \\
\hline $\begin{array}{l}\text { PHILIPPINES } \\
\text { PHIN }\end{array}$ & 0.30 & 7.78 & 0.13 & 0.12 & 16.50 & 1.39 \\
\hline UGANDA & 0.30 & 7.10 & 0.27 & 0.12 & 2.52 & -0.41 \\
\hline ZAIRE & 0.30 & 6.93 & 0.15 & 0.00 & 5.20 & $\begin{array}{l}-0.41 \\
-1.15\end{array}$ \\
\hline NICARAGUA & 0.30 & $\begin{array}{l}.9 .55 \\
8.45\end{array}$ & $\begin{array}{l}0.10 \\
0.19\end{array}$ & $\begin{array}{l}0.00 \\
0.00\end{array}$ & 12.19 & $\begin{array}{l}-1.15 \\
-2.24\end{array}$ \\
\hline MALI & 0.30 & $\begin{array}{l}8.45 \\
6.71\end{array}$ & $\begin{array}{l}0.19 \\
0.08\end{array}$ & $\begin{array}{l}.00 \\
0.12\end{array}$ & $\begin{array}{r}12.19 \\
5.89\end{array}$ & $\begin{array}{r}-2.24 \\
0.82\end{array}$ \\
\hline $\begin{array}{l}\text { MALI } \\
\text { SYRIA }\end{array}$ & $\begin{array}{l}0.30 \\
0.31\end{array}$ & $\begin{array}{l}6.11 \\
8.37\end{array}$ & $\begin{array}{l}0.08 \\
0.08\end{array}$ & $\begin{array}{l}0.12 \\
0.04\end{array}$ & $\begin{array}{r}5.89 \\
15.31\end{array}$ & $\begin{array}{l}0.82 \\
2.65\end{array}$ \\
\hline NIGERIA & 0.31 & $\begin{array}{l}0.01 \\
7.09\end{array}$ & $\begin{array}{l}0.0 \circ \\
0.14\end{array}$ & $\begin{array}{l}0.04 \\
0.00\end{array}$ & $\begin{array}{l}10.01 \\
15.06\end{array}$ & $\begin{array}{l}2.05 \\
1.89\end{array}$ \\
\hline PERU & $\begin{array}{l}0.31 \\
0.32\end{array}$ & 8.48 & 0.15 & 0.12 & 17.49 & $\begin{array}{l}1.09 \\
-0.56\end{array}$ \\
\hline HONDURAS & 0.34 & $\begin{array}{l}0.40 \\
7.71\end{array}$ & $\begin{array}{l}.10 \\
0.23\end{array}$ & 0.00 & 13.40 & $\begin{array}{r}-0.00 \\
0.84\end{array}$ \\
\hline INDONESIA & 0.37 & 6.99 & 0.11 & 0.81 & 21.57 & 4.74 \\
\hline CONGO & 0.37 & 7.60 & 0.08 & 0.00 & 9.24 & 2.85 \\
\hline GHANA & 0.37 & 7.45 & 0.21 & 0.23 & 5.05 & 0.07 \\
\hline SOMALIA & 0.37 & 7.51 & 0.09 & 0.00 & 9.85 & $\begin{array}{l}0.08 \\
-0.98\end{array}$ \\
\hline JORDAN & 0.41 & 8.04 & $\begin{array}{l}0.09 \\
0.09\end{array}$ & $\begin{array}{l}.00 \\
1.00\end{array}$ & $\begin{array}{r}7.00 \\
16.80\end{array}$ & $\begin{array}{r}-0.90 \\
2.43\end{array}$ \\
\hline PAKISTAN & $\begin{array}{l}0.41 \\
0.41\end{array}$ & $\begin{array}{l}7.04 \\
7.49\end{array}$ & $\begin{array}{l}.09 \\
0.03\end{array}$ & 0.00 & $\begin{array}{r}10.80 \\
9.57\end{array}$ & $\begin{array}{l}2.45 \\
1.76\end{array}$ \\
\hline ZAMBIA & $\begin{array}{l}0.41 \\
0.41\end{array}$ & $\begin{array}{l}.49 \\
7.66\end{array}$ & $\begin{array}{l}0.03 \\
0.54\end{array}$ & $\begin{array}{l}0.00 \\
0.00\end{array}$ & $\begin{array}{r}9.57 \\
15.98\end{array}$ & $\begin{array}{r}1.76 \\
-1.88\end{array}$ \\
\hline ARGENTINA & $\begin{array}{l}0.41 \\
0.43\end{array}$ & $\begin{array}{l}.0 .90 \\
8.97\end{array}$ & $\begin{array}{l}0.04 \\
0.05\end{array}$ & $\begin{array}{l}0.00 \\
0.00\end{array}$ & $\begin{array}{l}10.80 \\
16.87\end{array}$ & $\begin{array}{l}-1.00 \\
-0.25\end{array}$ \\
\hline MOROCCO & $\begin{array}{l}0.43 \\
0.43\end{array}$ & 7.80 & 0.11 & 0.23 & 11.22 & $\begin{array}{r}-0.23 \\
2.22\end{array}$ \\
\hline SRI LANKA & $\begin{array}{l}0.43 \\
0.43\end{array}$ & $\begin{array}{l}1.00 \\
7.67\end{array}$ & $\begin{array}{l}0.11 \\
0.15\end{array}$ & 0.23 & 10.93 & 2.30 \\
\hline TOGO & 0.44 & 6.82 & 0.19 & 0.00 & 18.35 & 1.07 \\
\hline EGYPT & 0.44 & 7.58 & 0.07 & 0.00 & 5.13 & 2.51 \\
\hline ALGERIA & 0.44 & 8.05 & 0.19 & 0.00 & 27.14 & 2.28 \\
\hline PARAGUAY & 0.44 & $\begin{array}{l}7.08 \\
7.88\end{array}$ & 0.10 & 0.08 & 15.53 & 2.06 \\
\hline ZIMBABWE & $\begin{array}{l}0.44 \\
0.44\end{array}$ & $\begin{array}{l}1.00 \\
7.58\end{array}$ & 0.17 & $\begin{array}{l}0.08 \\
0.00\end{array}$ & 14.87 & 0.86 \\
\hline $\begin{array}{l}\text { MALAWI } \\
\text { MALAD }\end{array}$ & $\begin{array}{l}0.44 \\
0.45\end{array}$ & $\begin{array}{l}1.58 \\
6.68\end{array}$ & $\begin{array}{l}0.11 \\
0.21\end{array}$ & $\begin{array}{l}0.00 \\
0.00\end{array}$ & $\begin{array}{l}14.87 \\
11.29\end{array}$ & $\begin{array}{l}0.80 \\
0.92\end{array}$ \\
\hline $\begin{array}{l}\text { MALAWI } \\
\text { DOMINICAN REP }\end{array}$ & $\begin{array}{l}0.45 \\
0.45\end{array}$ & $\begin{array}{l}0.68 \\
7.85\end{array}$ & $\begin{array}{l}0.21 \\
0.13\end{array}$ & $\begin{array}{l}0.00 \\
0.00\end{array}$ & $\begin{array}{l}11.29 \\
17.75\end{array}$ & $\begin{array}{l}0.92 \\
2.12\end{array}$ \\
\hline $\begin{array}{l}\text { TUNISIA } \\
\text { TUN REF }\end{array}$ & $\begin{array}{l}0.45 \\
0.46\end{array}$ & $\begin{array}{l}.85 \\
7.81\end{array}$ & $\begin{array}{l}0.13 \\
0.10\end{array}$ & 0.08 & 14.54 & 3.44 \\
\hline TANZANIA & $\begin{array}{l}0.46 \\
0.46\end{array}$ & $\begin{array}{l}1.01 \\
6.58\end{array}$ & 0.17 & $\begin{array}{l}0.00 \\
0.00\end{array}$ & 11.60 & $\begin{array}{l}.44 \\
1.93\end{array}$ \\
\hline MADAGASCAR & 0.47 & 7.63 & 0.12 & 0.00 & 1.39 & -1.99 \\
\hline JAMAICA & 0.47 & 8.32 & 0.14 & 0.38 & 18.85 & 0.78 \\
\hline SENEGAL & 0.48 & 7.69 & 0.14 & 0.00 & 5.11 & -0.01 \\
\hline BURKINA FASO & 0.48 & 6.52 & 0.04 & 0.00 & 9.49 & 1.26 \\
\hline URUGUAY & 0.51 & $\begin{array}{l}8.02 \\
8.67\end{array}$ & $\begin{array}{l}0.09 \\
0.09\end{array}$ & 0.04 & 14.34 & $\begin{array}{l}1.20 \\
0.88\end{array}$ \\
\hline TURKEY & $\begin{array}{l}0.51 \\
0.53\end{array}$ & $\begin{array}{l}8.01 \\
8.12\end{array}$ & $\begin{array}{l}0.04 \\
0.04\end{array}$ & $\begin{array}{l}0.08 \\
0.08\end{array}$ & $\begin{array}{l}14.34 \\
22.52\end{array}$ & $\begin{array}{l}0.00 \\
2.92\end{array}$ \\
\hline COLOMBIA & $\begin{array}{l}0.53 \\
0.53\end{array}$ & 8.19 & $\begin{array}{l}0.04 \\
0.09\end{array}$ & $\begin{array}{l}0.08 \\
0.19\end{array}$ & $\begin{array}{l}22.52 \\
15.66\end{array}$ & $\begin{array}{l}2.92 \\
2.39\end{array}$ \\
\hline GABON & 0.54 & 8.35 & 0.33 & $\begin{array}{l}0.19 \\
0.00\end{array}$ & $\begin{array}{l}10.00 \\
28.18\end{array}$ & 1.73 \\
\hline MEXICO & 0.54 & $\begin{array}{l}8.35 \\
8.82\end{array}$ & $\begin{array}{l}.33 \\
0.02\end{array}$ & $\begin{array}{l}.00 \\
0.19\end{array}$ & $\begin{array}{l}28.18 \\
17.09\end{array}$ & $\begin{array}{l}1.13 \\
2.22\end{array}$ \\
\hline SIERRA LEONE & 0.54 & $\begin{array}{l}.02 \\
7.60\end{array}$ & 0.09 & $\begin{array}{l}0.00 \\
0.00\end{array}$ & 1.37 & -0.83 \\
\hline ECUADOR & 0.54 & 8.05 & 0.11 & 0.69 & 22.91 & 2.21 \\
\hline COSTA RICA & 0.55 & 8.52 & 0.19 & 0.15 & 17.26 & 1.41 \\
\hline GREECE & 0.55 & 8.45 & 0.04 & $\begin{array}{l}.100 \\
1.00\end{array}$ & 24.57 & 3.17 \\
\hline VENEZUELA & 0.56 & $\begin{array}{l}9.60 \\
9.60\end{array}$ & 0.24 & 0.08 & 22.16 & $\begin{array}{r}0.11 \\
-0.84\end{array}$ \\
\hline KENYA & 0.56 & 7.14 & 0.18 & $\begin{array}{l}0.12 \\
0.12\end{array}$ & 14.52 & $\begin{array}{l}-0.04 \\
1.61\end{array}$ \\
\hline GAMBIA & $\begin{array}{l}0.56 \\
0.56\end{array}$ & $\begin{array}{l}.14 \\
7.17\end{array}$ & $\begin{array}{l}0.10 \\
0.36\end{array}$ & 0.19 & $\begin{array}{r}14.02 \\
6.05\end{array}$ & $\begin{array}{l}1.01 \\
0.35\end{array}$ \\
\hline CAMEROON & $\begin{array}{l}0.50 \\
0.57\end{array}$ & 7.10 & $\begin{array}{l}.30 \\
0.18\end{array}$ & $\begin{array}{l}.199 \\
0.00\end{array}$ & $\begin{array}{r}0.05 \\
10.59\end{array}$ & $\begin{array}{l}0.35 \\
2.40\end{array}$ \\
\hline CHINA & 0.57 & 6.94 & 0.02 & 0.00 & 20.48 & $\begin{array}{l}2.40 \\
3.35\end{array}$ \\
\hline INDIA & 0.58 & 7.21 & 0.02 & 0.00 & 14.19 & 2.03 \\
\hline NIGER & 0.58 & 7.12 & 0.05 & 0.00 & $\begin{array}{r}14.19 \\
9.37\end{array}$ & -0.69 \\
\hline TRINIDAD \& TOBAGO & 0.61 & 9.39 & 0.08 & $\begin{array}{l}0.00 \\
0.00\end{array}$ & 13.10 & 0.76 \\
\hline ISRAEL & 0.61 & 8.95 & 0.04 & 0.23 & 24.50 & 2.81 \\
\hline THAILAND & 0.63 & 7.71 & 0.09 & 1.00 & 17.56 & 4.59 \\
\hline CHILE & 0.63 & 8.69 & 0.15 & 0.58 & 18.18 & $\begin{array}{l}.09 \\
1.13\end{array}$ \\
\hline BRAZIL & 0.64 & $\begin{array}{l}8.09 \\
8.16\end{array}$ & $\begin{array}{l}0.105 \\
0.05\end{array}$ & $\begin{array}{l}0.00 \\
0.00\end{array}$ & $\begin{array}{l}10.10 \\
19.72\end{array}$ & $\begin{array}{l}1.10 \\
3.10\end{array}$ \\
\hline KOREA. REP. & $\begin{array}{l}0.04 \\
0.64\end{array}$ & $\begin{array}{l}8.10 \\
7.58\end{array}$ & $\begin{array}{l}.05 \\
0.02\end{array}$ & 0.88 & $\begin{array}{l}19.12 \\
26.97\end{array}$ & $\begin{array}{l}3.10 \\
7.41\end{array}$ \\
\hline IVORY COAST & $\begin{array}{l}0.64 \\
0.67\end{array}$ & $\begin{array}{r}7.58 \\
7.89\end{array}$ & 0.29 & $\begin{array}{l}0.88 \\
0.00\end{array}$ & $\begin{array}{l}26.97 \\
10.06\end{array}$ & $\begin{array}{r}7.41 \\
-0.56\end{array}$ \\
\hline MALAYSIA & 0.69 & 8.10 & 0.37 & 1.00 & 26.16 & 4.49 \\
\hline SOUTH AFRICA & 0.69 & 8.48 & 0.17 & 0.00 & 18.53 & 0.85 \\
\hline BOTSWANA & $\begin{array}{l}0.09 \\
0.70\end{array}$ & $\begin{array}{l}.40 \\
7.10\end{array}$ & 0.05 & $\begin{array}{l}0.42 \\
0.42\end{array}$ & $\begin{array}{l}10.50 \\
24.61\end{array}$ & $\begin{array}{l}0.00 \\
5.71\end{array}$ \\
\hline SPAIN & 0.76 & 8.87 & 0.03 & 1.00 & 25.05 & 2.95 \\
\hline PORTUGAL & 0.77 & 8.25 & 0.05 & 1.00 & 22.99 & 4.54 \\
\hline HONG KONG & 0.80 & 8.73 & 0.03 & 1.00 & 20.79 & 5.78 \\
\hline ITALY & 0.82 & $\begin{array}{l}9.07 \\
9.07\end{array}$ & 0.02 & 1.00 & 25.90 & 3.15 \\
\hline $\begin{array}{l}\text { TAIWAN } \\
\text { TAIWAN }\end{array}$ & $\begin{array}{l}0.02 \\
0.82\end{array}$ & 8.05 & $\begin{array}{l}0.02 \\
0.02\end{array}$ & 1.00 & 24.44 & $\begin{array}{l}6.135 \\
6.35\end{array}$ \\
\hline IRELAND & $\begin{array}{l}0.82 \\
0.83\end{array}$ & $\begin{array}{l}8.05 \\
8.84\end{array}$ & $\begin{array}{l}.02 \\
0.15\end{array}$ & 0.96 & $\begin{array}{l}24.44 \\
25.94\end{array}$ & $\begin{array}{l}0.35 \\
3.37\end{array}$ \\
\hline $\begin{array}{l}\text { 1RELAND } \\
\text { SINGAPORE }\end{array}$ & $\begin{array}{l}0.83 \\
0.86\end{array}$ & $\begin{array}{l}8.84 \\
8.15\end{array}$ & $\begin{array}{l}0.15 \\
0.03\end{array}$ & $\begin{array}{l}0.96 \\
1.00\end{array}$ & $\begin{array}{l}25.94 \\
36.01\end{array}$ & $\begin{array}{l}3.37 \\
7.39\end{array}$ \\
\hline FRANCE & 0.93 & $\begin{array}{l}.100 \\
9.37\end{array}$ & $\begin{array}{l}0.03 \\
0.03\end{array}$ & 1.00 & $\begin{array}{l}30.01 \\
26.72\end{array}$ & 2.58 \\
\hline U.K. & 0.93 & 9.38 & 0.03 & 1.00 & 18.12 & 2.18 \\
\hline JAPAN & 0.94 & $\begin{array}{l}9.30 \\
8.79\end{array}$ & 0.01 & $\begin{array}{l}1.00 \\
1.00\end{array}$ & $\begin{array}{l}10.12 \\
34.36\end{array}$ & $\begin{array}{l}2.10 \\
4.66\end{array}$ \\
\hline AUSTRALIA & $\begin{array}{l}0.94 \\
0.94\end{array}$ & $\begin{array}{l}8.19 \\
9.57\end{array}$ & $\begin{array}{l}.01 \\
0.10\end{array}$ & 1.00 & $\begin{array}{l}34.30 \\
27.44\end{array}$ & $\begin{array}{l}4.00 \\
1.97\end{array}$ \\
\hline AUSTRIA & 0.95 & 9.18 & 0.04 & 1.00 & 25.89 & 2.91 \\
\hline GERMANY. WEST & 0.96 & 9.41 & 0.02 & 1.00 & 25.71 & 2.37 \\
\hline NORWAY & 0.96 & 9.30 & 0.10 & 1.00 & 32.50 & 3.05 \\
\hline SWEDEN & 0.97 & $\begin{array}{l}9.50 \\
9.56\end{array}$ & 0.05 & 1.00 & $\begin{array}{l}32.30 \\
22.38\end{array}$ & $\begin{array}{l}1.80 \\
1.80\end{array}$ \\
\hline NEW ZEALAND & 0.97 & $\begin{array}{l}9.00 \\
9.63\end{array}$ & $\begin{array}{l}.05 \\
0.18\end{array}$ & $\begin{array}{l}1.00 \\
0.19\end{array}$ & $\begin{array}{l}22.38 \\
23.79\end{array}$ & $\begin{array}{l}1.80 \\
0.97\end{array}$ \\
\hline CANADA & $\begin{array}{l}0.97 \\
0.97\end{array}$ & $\begin{array}{l}9.63 \\
9.60\end{array}$ & $\begin{array}{l}0.18 \\
0.10\end{array}$ & $\begin{array}{l}0.19 \\
1.00\end{array}$ & $\begin{array}{l}23.79 \\
24.26\end{array}$ & $\begin{array}{l}0.97 \\
2.74\end{array}$ \\
\hline DENMARK & 0.97 & 9.47 & 0.10 & 1.00 & 24.42 & 2.01 \\
\hline FINLAND & 0.97 & $\begin{array}{l}9.41 \\
9.21\end{array}$ & 0.07 & 1.00 & 33.81 & 3.08 \\
\hline BELGIUM & 0.97 & 9.27 & 0.11 & 1.00 & 22.26 & $\begin{array}{l}0.00 \\
2.70\end{array}$ \\
\hline U.S.A. & $\begin{array}{l}0.98 \\
0.98\end{array}$ & $\begin{array}{l}9.87 \\
9.87\end{array}$ & $\begin{array}{l}.111 \\
0.01\end{array}$ & $\begin{array}{l}1.00 \\
1.00\end{array}$ & 22.83 & 1.76 \\
\hline NETHERLANDS & $\begin{array}{l}0.98 \\
0.98\end{array}$ & $\begin{array}{l}9.87 \\
9.38\end{array}$ & $\begin{array}{l}0.01 \\
0.15\end{array}$ & $\begin{array}{l}1.00 \\
1.00\end{array}$ & $\begin{array}{l}22.83 \\
23.32\end{array}$ & $\begin{array}{l}1.76 \\
2.27\end{array}$ \\
\hline SWITZERLAND & 1.00 & 9.74 & 0.02 & 1.00 & 28.88 & 1.57 \\
\hline
\end{tabular}

The variables are: IQ - an index of institutional quality,
LGDPEA - the log of GDP per head of the economically active population in 1965

SXP - the share of primary exports in GNP in 1970, OPEN - an index of a country's openness INV - the average ratio of real gross domestic investments over GDP

Table 4: Dataset used in the main regression. 